Hannah Strømmen, "The Politics of the Beast: Rewiring Revelation 17," Relegere: Studies in Religion and Reception 7, nos. I-2 (2018): 147-64.

(c) BY-NC-ND This work is licensed under a Creative Commons Attribution Non-Commercial No Derivatives 3.o License.

Relegere: Studies in Religion and Reception is an independent, open-access academic journal dedicated to the promotion and dissemination of innovative research in reception history, broadly conceived, within and across religious traditions.

www.relegere.org

ISSN I I 79-723 I 


\title{
Hannah Strømmen
}

\section{The Politics of the Beast}

\author{
Rewiring Revelation 17
}

Revelation's Whore of Babylon and the hybrid animal upon which she rides provide a female-beastly assemblage against which is constructed the good sovereignty of the Lamb. Derrida's thinking of animality and sovereignty indicates how the human political realm carves out its sovereign position in relation to the category "animal" and in reliance on a "reason of the strongest." It is demonstrated that Revelation's construction of a good and innocent sovereign Lamb_via contrast with the Whore-and-Beast-collapses due to the complexities of the two rival animalities. The importance of such a reading lies in the necessity to destabilise facile connotations and connections between animals and an "other" beastliness that must be violently conquered.

T n April 2015, English TV and social media personality Katie Hopkins 1 called migrants trying to get to Europe "cockroaches," and in November 2015, English newspaper the Daily Mail published a cartoon likening refugees to rats. ${ }^{1}$ In a Guardian article from 2013, Shaker Aamer stated that

Hannah Strømmen is Senior Lecturer in Biblical Studies at the University of Chichester.

${ }^{1}$ The comments were printed in the Sun but have since been removed. See Zoe Williams's comment on Hopkins's remarks in "Katie Hopkins calling migrants vermin recalls the darkest events of history," Guardian, April 19, 2015, https://www.theguardian.com/ 
he and other detainees of Guantánamo Bay were treated like animals. ${ }^{2}$ Implicitly, the "we" that pronounces others "animal" situate themselves in a sovereign position, justified in waging a war on the "unhuman" other. The use of animals to denote negative characteristics arises out of centuries of reliance on a distinction-strikingly dogmatic and strategically dynamicbetween what is "human" and what is "animal." It is this distinction that Jacques Derrida sets out to critique in his later work on animals, particularly in the posthumously published The Animal That Therefore I Am (2008) and The Beast and the Sovereign volumes (2009 and 201 I). ${ }^{3}$ Derrida argues that thinking in terms of "the animal" as absolutely set apart from humans is a way of legitimating the violence done in the name of a human sovereignty, and becomes a strategic way of excluding certain groups or figures (human and non-human) as other, inferior, objectifiable.

One of the most influential texts to use animal imagery to construct a good sovereignty against an animalised — or rather beastly—other is the last book of the New Testament, the book of Revelation. In particular, the combination of Whore of Babylon and the hybrid animal-beast she rides in Rev I7 has been, and still is, a ceaselessly productive machine for indicating and indicting political evil. The Whore-and-Beast is an assemblage that continues to demonise "enemies" but also the female and animal. As Steve Baker points out, in examining the animals that inhabit culture it is noteworthy that they seem to have little to do with "real, living animals." ${ }^{4}$ This could also be said of the "bizarre bestiary" in Revelation. ${ }^{5}$ Nonetheless, I share Baker's convic-

commentisfree/201 5/apr/I 9/katie-hopkins-migrants-vermin-darkest-history-drownings. Likewise (presumably due to the numerous complaints), the Daily Mail article cannot now be accessed, but see Aubrey Allegretti, "Daily Mail Cartoon Comparing Refugees To Rats Is 'Islamophobic,' Richard Burgon MP Claims," Huffington Post, November I9, 2015, http://www.huffingtonpost.co.uk/2015/1 I/19/daily -mail-mac-cartoon-muslims-rats-islamophobic-letter-richard-burgon_n_8600328.html.

${ }^{2}$ Richard Norton-Taylor, "Last British resident in Guantánamo Bay: we are treated like animals," Guardian, November I 8, 2013, https://www.theguardian.com/world/2013/nov/ I 8/guantanamo-bay-british-resident. For an in-depth discussion and analysis of depictions of animals in the political realm, see Steve Baker, Picturing the Beast: Animals, Identity, and Representation (Manchester: Manchester University Press, I993).

${ }^{3}$ The Animal That Therefore I Am, ed. Marie-Louise Mallett, trans. David Wills (New York: Fordham University Press, 2008) is a collection from Derrida’s Cérisy lectures in I997, and the two volumes of The Beast and the Sovereign, trans. Geoffrey Bennington (Chicago: University of Chicago Press, 2009, 20 I I) are transcribed from his final 200 I-2003 seminars.

${ }^{4}$ Baker, Picturing the Beast, 3 .

${ }^{5}$ Stephen D. Moore, "Ecotherology," in Divinanimality: Animal Theory, Creaturely The- 
tion that strategies that seek to advocate for animals must be informed by the ways in which animal imagery and symbolism operate in contemporary cultural practices. ${ }^{6}$ I would add that often such contemporary practices are grounded in ancient and obstinate perceptions of animality that are uncritically perpetuated.

In this article, I will first discuss the ways in which the female-animal assemblage of Revelation gains political currency throughout history as an emblem of evil. Turning then to Derrida's thinking of animality and sovereignty, it becomes clear how the human political realm sets up a sovereign position to carve out a space of power in relation to the category "animal" that relies on a "reason of the strongest." Resisting this reasoning, Derrida attempts to think a deconstructed sovereignty. Rewinding back to the text of Rev I7, I demonstrate the way we might think of the Whore-and-Beast as a deconstructed sovereignty. Ultimately, I show that the construction of a good and innocent sovereignty against an evil, beastly sovereignty collapses, and the "beastly" figures take on a more complex visage. The importance of such a reading lies in the necessity to destabilise facile connotations and connections between animals and an "other" beastliness that must be violently conquered. ${ }^{7}$

\section{A Biblical-Political Assemblage of Evil}

The book of Revelation is well known for its political animals. As Norman Cohn points out, Revelation has "proved extraordinarily adaptable and longlived." ${ }^{8}$ The text is frequently treated as a tantalizing "book of puzzles" or a "code to be cracked." Arguably, this has contributed to its "remarkable resilience" in the numerous and differing attempts to understand the significance of the figures of Revelation for the past, the present day, and the future. ${ }^{10}$ Part of this interpretation-drive lies in the attention given to the

ology, ed. Stephen D. Moore (New York: Fordham University Press, 2014), 197.

${ }^{6}$ Baker, Picturing the Beast, 5 .

${ }^{7}$ In this article I rework material from my chapter, "Bodies of the Beast," in Biblical Animality after Jacques Derrida (Semeia Studies 9I; Atlanta: SBL Press, 20 I 8), from the perspective of biblical reception history. I am grateful to SBL for granting permission for this.

${ }^{8}$ Norman Cohn, "Biblical Origins of the Apocalyptic Tradition," in The Apocalypse and The Shape of Things to Come, ed. Frances Carey (London: British Museum Press, 1999), 4I.

${ }^{9}$ Ian Boxall, "The Apocalypse Unveiled: Reflections on the Reception History of Revelation," Expository Times I25, no. 6 (2013), 262.

${ }^{10}$ Ibid. 
"beastly" figures to be found in Revelation, and relatedly, to the political imaginary they plug into. Joachim of Fiore, for instance, saw the sevenheaded dragon of Rev $\mathrm{I} 2$ as Herod and Nero, as well as his own contemporary, Saladin, while Martin Luther famously recognised the "papists" of his day in the Whore of Babylon. ${ }^{11}$

Revelation 17 presents a particularly potent assemblage of beastly evil in the form of the Whore-and-Beast. In this chapter, human political power is represented as "beastly," through the animal and the female, while divine sovereignty is represented as a Lamb. Here the human-political and the divine-political are both cast as animals in competing constellations of power. The Beast ${ }^{12}$ of Revelation is a hyperbolic hybrid creature, described in Rev 13 as "a leopard, its feet were like a bear's, and its mouth was like a lion's mouth" (I 3:2); it is "scarlet," "full of blasphemous names," with "seven heads and ten horns" ( $7: 3$ ), the heads representing kings "of whom five have fallen, one is living, and the other has not yet come" (I 7: Io). ${ }^{13}$ A belligerent figure, with "power and authority" (I 7: I3), it is war-mongering, making war on the Lamb and those that are "called, chosen and faithful" (I7:I4). The Whore too is a sovereign power in opposition to the Lamb, equally if not more bellicose; simultaneously described as a "whore" (I7:I), "woman" (I 7:3), and "queen" (I 8:7), she rides the Beast, rules "over the kings of the earth" (I7:I 8), and manages to do all this while being drunk on the "blood of the saints and the blood of the witnesses to Jesus" (I 7:6).

The many-headed Beast and the Whore of Babylon are presented as a human form of sovereignty, alluding to Roman imperial rule. But as already mentioned with regards to Joachim of Fiore and Luther, the Beast and the Whore have not remained static images for first-century Roman rule. In

${ }^{11}$ Ibid., 267.

${ }^{12}$ It is in some ways unclear whether the Beast described in Rev 13 is the same as the scarlet Beast in Rev 17; they are explicitly connected by both being described as having seven heads and ten horns and so in this sense I treat them as one Beast. But there is also the second beast mentioned in I 3:I I (that pays obeisance to the first), with "two horns like a Lamb" and speaking like a dragon, as well as the "great red dragon, with seven heads and ten horns" ( $2: 3$ ). While I focus on the description of the Whore-and-Beast in battle with the Lamb in Rev 17 and relate it to the description of the Beast in $13: 2$, the whole array of beastly imagery participates in the logic of evil animal (Beast) against the good and divine animal (Lamb). The assemblage of beastly figures throughout Revelation could be seen as one hybrid "Beast," or an enemy assemblage that alludes to the animals in the Roman arena, as I go on to discuss, in the sense that they play the part of ferocious enemy to be defeated in a theatrical spectacle mimicking an arena battle.

${ }^{13}$ All biblical citations are from the NRSV Anglicised Version. 
the twenty-first century, President Obama has been represented as a Beast by political enemies, ${ }^{14}$ while American preacher Hal Lindsey associates the Beasts of Revelation with the European Union. ${ }^{15}$ To smear the European Union, some have suggested that the Beasts are housed in Europe in the form of a "super-computer" in Brussels. ${ }^{16}$ Looking back historically, the Beast coming out of the sea has represented the English at war with the French in the fourteenth century, ${ }^{17}$ while during the Napoleonic Wars in the early nineteenth century, Germans saw the Beast as Napoleon and Paris as the Great Whore. ${ }^{18}$

Imagery pertaining to the Crusades gets caught up in depictions of the Whore in, for example, the Flemish Apocalypse (ca. I400) which shows men representing crusaders attacking the Whore. The Whore is here linked with the Eastern "other," the enemy of the Crusaders, an association that is taken up also by Albrecht Dürer and later by William Blake in their depictions of the Whore. ${ }^{19}$ The depiction of the Whore in this guise demonstrates an early version of the Western interpretation of the East (or Middle East) as alien, exotic, and licentious. ${ }^{20}$ The identification of the Whore of Babylon with the Catholic papacy emerged during the Reformation, as already mentioned, when Martin Luther compared the excesses and hypocrisy of the Whore to the popes of his day; but this idea had already been prefigured by radical Franciscans and Wycliffites. ${ }^{21}$ In more modern times, the Beastly imagery in Revelation has been used to represent the South African government and Dutch Reformed Church during Apartheid, as well as to represent the nuclear bomb in the I970s. ${ }^{22}$ From the Napoleonic Wars, to the First World War, the Cold War, Hillary Clinton, and the materialism and promiscuity (as some deem it) of modern America, the Whore-and-Beast became an emblem for a multifaceted assemblage of political evil. ${ }^{23}$

${ }^{14}$ Natasha O'Hear and Anthony O'Hear, Picturing the Apocalypse: The Book of Revelation in the Arts over Two Millennia (Oxford: Oxford University Press, 201 5), I 39.

${ }^{15}$ Ibid., I 52.

${ }^{16} \mathrm{Ibid}$.

${ }^{17}$ Ibid., I 4I.

${ }^{18}$ Arthur W. Wainwright, Mysterious Apocalypse: Interpreting the Book of Revelation (Nashville: Abingdon Press, 1993), I70-7I.

${ }^{19}$ O'Hear and O'Hear, Picturing the Apocalypse, I64-66.

${ }^{20}$ Ibid.

${ }^{21}$ Ibid., I $55-57$.

22 Wainwright, Mysterious Apocalypse, I 83-84.

${ }^{23}$ For more detailed discussion, see O'Hear and O'Hear, Picturing the Apocalypse, I70-75. 
It is clear that these "beastly" figures have become efficacious modes of designating (theo)political evil, linking the Beast and the Whore to what is seen as base in the human world. In other words, what Rev 17 might be said to do is to provide an effective model, or machine, for indicating and indicting different forms and figures of evil. The Whore and Beast together are a particularly effective — and affective-assemblage for political evil. As I go on to discuss, the "female" nature of the Whore is a key aspect of this efficacy, but the animality is also central; the Whore is deliberately animalised while the Beast comes in hyper-animalised form by being assembled from several wild animals. In his work on the role animals (or "the animal") have played, Derrida discusses the paradoxes in designating sovereignty as properly human against an animal other, while at the same time the political has frequently been construed as animal. Turning to his work, we might begin to discern what is at stake in this paradox and in the animal politics of Rev 17. Through Derrida's deconstructed sovereignty, it might be possible to rethink the terms in which the political becomes caught up in a reasoning that rests on the (violent) exclusion of the/an other.

\section{Deconstructed Sovereignty}

In Derrida's later work, he examines the discursive apparatus of humananimal difference- the kind of apparatus that allows us to, as Derrida puts it, "organize on a global scale the forgetting or misunderstanding" of organised violence against animals, "which some would compare to the worst cases of genocide." ${ }^{4}$ The reference to "genocide" as a term normally reserved for human massacres is not incidental; Derrida is deliberately attempting both to force attention to the suffering of animals for the putative well-being of "man," and, at the same time, obliquely point to the ways in which human genocides are frequently justified by deeming its victims nonhuman. As Neil Badmington affirms, "not only does he cast a suspicious glance on the idea that there is anything proper (which is to say, essential in an exclusive and binary sense) to human beings, but he also interrogates the manner in which the logic of the proper functions to draw a simple and reductive dividing line between human and animal."25

In The Beast and Sovereign vol. I, Derrida explores the idea of sovereignty as a dominant conceptualisation of the human in relation to the subjection

${ }^{24}$ Derrida, The Animal, 26.

${ }^{25}$ Neil Badmington, "Derridanimals," Oxford Literary Review 29, no. I-2 (2007), 2. 
of those it calls "animal." 26 The perception of this sovereignty has, he argues, been translated into a "reason of the strongest," that is a reasoning or logic in which what is construed as the exclusive powers of the human-such as precisely "reason"- constitute a sovereign strength in the face of those that are deemed "animal." On the one hand, then, the human as a political animal is "superior, in his very sovereignty, to the beast that he masters, enslaves, dominates, domesticates, or kills, so that his sovereignty consists in raising himself above the animal and appropriating it, having its life at his disposal." 27 On the other hand, however, conceptions of the human-political realm are frequently characterised as animal or beast-like. ${ }^{28}$ This paradox is mirrored in the way animals have tended to be seen as either naturally innocent, "without consciousness of good and evil," 29 and therefore outside the moral-political realm, or, as representing "evil," in the form of the beast, marked by brutality, poorly controlled instincts, the irrationality of the living being; attributes that can bleed into the human political realm and must therefore be suppressed, externalised, kept at bay. ${ }^{30}$ This is how we might read the Lamb as a designation of innocence, outside the human-political realm, while the Whore-Beast represents the brutality and "beastliness" of human-political sovereignty.

In Rogues, Derrida explores the idea of a deconstructed sovereignty. $\mathrm{He}$ attempts to think a deconstructed sovereignty through the inversion of the idea of a sovereign God: "wherever the name of God would allow us to think something else, for example a vulnerable nonsovereignty, one that suffers and is divisible, one that is mortal even, capable of contradicting itself or of repenting (a thought that is neither impossible nor without example), it would be a completely different story, perhaps even the story of a god who deconstructs himself in his ipseity." 31 Invoking Jeremy Bentham's famous question, can animals suffer?, Derrida's deconstructed sovereignty is a matter

${ }^{26}$ Derrida briefly mentions "the beasts from John's Revelation," as political figures, "the reading of which would merit more than one seminar," (Derrida, The Beast, I:24) a reading which Derrida does not undertake.

${ }^{27}$ Ibid., 26.

${ }^{28}$ Ibid. On ways in which "beast" is used as the negative or positive image for humanity, see also Mary Midgley, Beast and Man: The Roots of Human Nature (Ithaca: Cornell University Press, I978).

${ }^{29}$ Derrida, The Animal, 5.

${ }^{30}$ Derrida, The Beast, I:44-45.

31 Jacques Derrida, Rogues: Two Essays on Reason, trans. Pascale-Anne Brault and Michael Naas (Stanford: Stanford University Press, 2005), I 57. 
of thinking a power without power. ${ }^{32}$ He wants to think a capability or attribute, a power of nonpower, the power or capability to suffer: "Mortality resides there, as the most radical means of thinking the finitude that we share with animals, the mortality that belongs to the very finitude of life, to the experience of compassion, to the possibility of sharing the possibility of this nonpower," "the anguish of this vulnerability." 33 A struggle has been taking place, which Derrida calls "a war," between "on the one hand, those who violate not only animal life but even and also this sentiment of compassion, and, on the other hand, those who appeal for an irrefutable testimony to this pity": a war in other words, "waged over the matter of pity." 34 We are passing through a critical phase, he suggests, that is inescapable, to "think the war we find ourselves waging." 35 Deconstructing sovereignty, he argues, can begin to reconfigure the "war" waged against the Animal as the other, either outside morality or as a figure of evil that must be conquered. It is a matter, as Laurel Kearns puts it, of "opening wide spaces for reimagining" the relationship between "human" and "animal."36

If the Whore and the Beast of Rev I7 have been used to configure a war on numerous "enemies" in differing contexts, then they have also been used-at least implicitly but often also explicitly—to denigrate the female and the animal (or female-as-animal, animal-as-female) by imagining political evil as female-animal. Feminists have long recognised that Revelation is a problematic book. ${ }^{37}$ But arguably it is necessary to think not only in terms of how the "female" is depicted but specifically how the female is animalised, or thought of as-animal, and how animality becomes a vehicle for upholding a belligerent sovereign position against an enemy. In The Sexual Politics of Meat: A Feminist-Vegetarian Critical Theory, Carol Adams writes: "People with power have always eaten meat." 38 Echoing Adams, Derrida asks:

${ }^{32}$ Derrida, The Animal, 27.

${ }^{33}$ Ibid., 28.

${ }^{34}$ Ibid., 28-29.

${ }^{35}$ Ibid.

${ }^{36}$ Laurel Kearns, "Foreword," in Divinanimality: Animal Theory, Creaturely Theology, ed. Stephen D. Moore (New York: Fordham University Press, 20I4), xiv.

${ }^{37}$ See, for instance, Tina Pippin, Death and Desire: The Rhetoric of Gender in the Apocalypse of John (Louisville: Westminster John Knox Press, 1992); Apocalyptic Bodies: The Biblical End of the World in Text and Image (London: Routledge, 1999); Catherine Keller, Apocalypse Now and Then: A Feminist Guide to the End of the World (Boston: Beacon Press, 1996).

${ }^{38}$ Carol J. Adams, The Sexual Politics of Meat: A Feminist-Vegetarian Critical Theory, 2oth anniversary edition (New York: Continuum, 20 Io), 48. 
who could be Head of State and declare himself, publicly, a vegetarian?39 Through her examination of cook books, fairy tales, and discourse on food in politics and culture more generally, Adams argues that a mythology is at work where meat-eating is an intimately masculine activity and a symbol of patriarchy. The pieces of meat are "female-identified" as flesh to be subjugated and controlled. ${ }^{40}$ Adams demonstrates how cultural images of sexual violence intersect with images of the butchering and eating of animals, especially in the sex industry where women become objects of consumption to their male customers, but also in, for instance, the chains, cattle prods, dog collars, and ropes used in pornography to control the "animal" woman. ${ }^{41}$

The killing of wild animals is linked to demonstrations of masculine power, just as might be seen in Rev 17 with the triumph of the Lamb involving the killing and eating of the wild Whore and the conquering of the wild and ferocious Beast. The slaughtered animal is associated with a ferociousness that must be controlled, evoking notions of "territorial imperative, armed hunting, aggressive behaviour, the vitality and virility of meat eating." ${ }^{42}$

Through symbolism based on killing animals, we encounter politically laden images of absorption, control, domain, and the necessity of violence. This message of male dominance is conveyed through meat eating - both in its symbolism and reality. ${ }^{43}$

It is through the specifically animalised imagery that the Whore-and-Beast becomes a legitimate target for violence, while sympathy is exclusively invoked for the Lamb. The Whore is eventually laid bare, eaten, and burnt ( I 7: I6), as if a sacrifice tinged with sexual violence. Yvonne Sherwood argues that sacrifice itself could be read as a way of erecting distinctions between the humans that sacrifice, the animals that are sacrificed, and the gods that are

39 Jacques Derrida, “'Eating Well,' or the Calculation of the Subject," in Points ... Interviews, 1974-1994, ed. Elisabeth Weber, trans. Peter Connor and Avital Ronell (Stanford: Stanford University Press, 1995), 28 I.

${ }^{40}$ Adams, Sexual Politics of Meat, 242.

${ }^{41}$ See in particular the chapter "The Rape of Animals, the Butchering of Women," in Sexual Politics of Meat, 64-9I.

${ }^{42}$ Adams, Sexual Politics of Meat, 244.

${ }^{43}$ Ibid. 
the receivers of sacrifice. ${ }^{44}$ But it is also about dissolving such distinctions. "It is," she suggests, "about 'cutting up life,' in the sense of establishing the conceptual divisions that help us make sense of life." 45 In Rev I7, the Whore is carved up as edible flesh and the Beast is sent to its destruction. Instead of being presented as strategies for cutting up life, however, the violence against the Beast and Whore is seemingly naturalised as legitimate because Rome as political evil is presented as "a monstrous aberration" akin to "a hideous Beast that derives its ultimate authority from Satan (I 3:4, 8, I2, I 4-I 5; cf. I 4:9-I I; I 6:2; I 9:20; 20:4)." ${ }^{46}$ But can this machinery be wired otherwise?

\section{Revelation 17 Rewired}

In Rev 17 it is the Lamb that wins, that becomes the conquering power, "Lord of lords, King of kings" ( I 7:I4). In opposition to the ferocious sovereign figures of the Whore and the Beast, the imagery of the Lamb denotes innocence and sacrificial, saving powers. ${ }^{47}$ Christopher Rowland emphasises the significance of such a "weak creature" as an "agent of God's purposes." 48 He argues that this is God's way of being present, as the Lamb on the throne. ${ }^{49}$ As the throne denotes, this Lamb then is also a sovereign force. The aim is for the "kingdom of the world" to become "the kingdom of our Lord" (I I:I 5 ) "for you have taken your great power and begun to reign" (I I:I8). It is God who will be "King of the nations" ( $15: 3$ ), not the Whore-and-Beast. As a sovereign Lamb, the divine-political is seemingly thus represented as a weak power. ${ }^{50}$ Notably, however, the weak power of the Lamb is triumphant: in $17: 14$, the Beast and its kings "will make war on the Lamb," but "the

${ }^{44}$ Yvonne Sherwood, "Cutting up Life: Sacrifice as a Device for Clarifying-and Tormenting-Fundamental Distinctions between Human, Animal, and Divine," in The Bible and Posthumanism, ed. Jennifer L. Koosed (Atlanta: Society of Biblical Literature, 2014).

45 Ibid., 25 I.

${ }^{46}$ Stephen D. Moore, Empire and Apocalypse: Postcolonialism and the New Testament (Sheffield: Sheffield Phoenix Press, 2006), ro5.

${ }^{47}$ In Exodus, followers of God are saved by the blood of the Passover lamb while the Egyptians are punished. For further discussion of the connection between Revelation and Exodus, see Matthias Reinhard Hoffmann, The Destroyer and the Lamb: The Relationship between Angelomorphic and Lamb Christology in the Book of Revelation (Tübingen: Mohr Siebeck, 2005), 250.

${ }^{48}$ Christopher Rowland, Revelation (London: Epworth Press, I993), 75.

${ }^{49}$ Ibid., 64.

50 For further christological discussions of the lamb, see Hoffmann, Destroyer and the Lamb. 
Lamb will conquer them, for he is Lord of Lords and King of kings" (I 7: I4). The Lamb thus plays into what Derrida describes as "essential and proper to sovereignty": "not grandeur or height ... but excess, hyperbole, an excess insatiable for the passing of every determinable limit: higher than height, grander than grandeur, etc." ${ }^{51}$ As Stephen Moore puts it, the paradox of the Lamb is that it appears to be a docile and domesticated trope for domination which becomes a monstrous agent of terror, ${ }^{52}$ whose God is as terrifying as the Beast in his "great supper" of "the flesh of all," animals and humans alike (19: I7-I8).

The Beast, then, becomes a victim to this more "proper" form of sovereignty. The Lamb does not remain an "innocent" animal figure outside the ethical-political realm, and the Beast does not, perhaps, simply signify active, belligerent violence. In fact, if we actually attend to the animality of the Beast and do not immediately rush to a reading that emphasises the various human figures of imperial power the Beast may denote-may "really" be about - a rather different picture emerges than merely one of unadulterated evil. As already mentioned, the Beast with ten horns and seven heads is in Rev I 3 described "like a leopard, its feet were like a bear's, and its mouth was like a lion's mouth" (I 3:2). The idea of the beastly imagery with many heads, horns, and resembling multiple animals, evokes the monstrous. But the idea of such a hybrid animal, and the very idea of a many-headed "Beast," could be read in light of the lives of animals in the Roman Empire, as suggested in Christopher Frilingos's incisive study on spectatorship and the Roman arena in Revelation, Spectacles of Empire: Monsters, Martyrs, and the Book of Revelation. ${ }^{53}$ Following Frilingos, Robert Seesengood deems Revelation to be more like a spectacle than a vision. ${ }^{54} \mathrm{He}$ argues that the "repeated pattern of combat scenes and exotic displays found in the Apocalypse may be deliberately evocative of the spectacles of the Roman arena." 55

Embedded in the language of games, sports, and violence in the Roman arenas that are reflected in Revelation, I suggest that the particular discourse of animality and sovereignty is paramount for constructing sympathy

${ }^{51}$ Derrida, The Beast, I:257.

${ }^{52}$ Moore, "Ecotherology," 202, I99.

${ }^{53}$ Christopher A. Frilingos, Spectacles of Empire: Monsters, Martyrs, and the Book of Revelation (Philadelphia: University of Pennsylvania Press, 2004), I.

${ }^{54}$ Robert P. Seesengood, Competing Identities: The Athlete and the Gladiator in Early Christian Literature (London: T\&T Clark, 2006), 74.

${ }^{55}$ Ibid., 75. 
for the good "team" - the Lamb—and antipathy for the bad "team"- the Beast and Whore. The war between Lamb and Beast could be seen as a battle of beastly Roman power against its innocent opponents. Polemically construed as (Christian) humans treated like lambs, such opponents are portrayed in Rev I7 as if a lamb thrown to the wild beasts of the Roman arenas. Revelation provides a "textual theatre" that narrates spectacles for its ancient Christian audience, drawing on available discourses in the Roman Empire. ${ }^{56}$ Frilingos suggests that such spectacles were a "particularly effective mode for the production of authoritative knowledge about other and self under the Roman Empire." ${ }^{57}$ The Beast of Revelation, then, plays the part of the other, and is necessarily the opposing team that conjures up antipathy amongst those identifying with the Lamb. As animal figures in this textual theatre, Lamb and Beast represent different types of sovereignty, the first an innocent and weak but true sovereignty, and the latter as the powerful, evil sovereignty that must be defeated for the true sovereignty to reign. This opposition of "good" against "evil" works so well because the weak-innocent animal against a hybrid-wild beastly force plays upon a spectrum of animality where "the animal" is both, as Derrida points out, seen as innocent creature outside the human ethical-political realm, and as the beastly aspect of human nature that must be actively excluded from this realm. The Lamb can thus function as the former and the Beast as the latter-both animal figures but representing different forms of animality and different types of sovereignty.

Ingvild Sælid Gilhus explains one particularly pertinent performance of Roman power involving animals, namely the hunting spectacles that took place in arenas, often involving large numbers of animals being killed as a form of mass entertainment in antiquity. ${ }^{58}$ In the Roman arenas animals

${ }^{56}$ Frilingos, Spectacles of Empire, 40.

57 Ibid., I I.

${ }^{58}$ Ingvild Sælid Gilhus, Animals, Gods, and Humans: Changing Attitudes to Animals in Greek, Roman, and Early Christian Thought (London: Routledge, 2006), 3 I. The first such known hunting spectacle, involving lions and panthers, was in I $86 \mathrm{BCE}$ organised by Marcus Fulvius Nobilior (Livy, Ab urbe cond. 39.5.7-10; 39.22.2). Ibid. For more on this, see John P. V. D. Balsdon, Life and Leisure in Ancient Rome (London: Bodley Head, I 969); Kathleen M. Coleman, "Fatal Charades: Roman Executions Staged as Mythological Enactments," Journal of Roman Studies 80 (1990): 44-73. For animals in Rome more generally, see particularly Jocelyn Toynbee, Animals in Roman Life and Art (Baltimore: John Hopkins University, I996). The damnatio ad bestias was introduced for deserters in the middle of the second century BCE by Scriptio the Younger and took on increasing popularity as a form of punishment. Gilhus, Animals, Gods, and Humans, 33. Also, see Olivia F. Robinson, Ancient Rome: City Planning 
were both imported and indigenous, carnivorous and herbivorous, wild and domestic; they had to be captured, put in menageries, and then were kept in cages in lower levels of the Colosseum and special areas outside the city. ${ }^{59}$ For the fights animals were brought into arenas in Rome: "bulls were set against panthers, rhinoceroses against bears and lions against tigers, as well as all types of animal against humans." 60 The Beast of Revelation who is leopard, bear, and lion could be read as an amalgamation of such animals used for Roman spectacles, pointing quite literally to the beastly powers of Rome. Seen in this light, the Beast is not merely the ferocious, many-headed, derogatory representation of violence but the vulnerable, victimized, exploited bodies of the hunted, captive animals in a brutalising arena. While these animals may well be ferocious, their place in such a context is also that of creatures robbed of their habitat and freedom, forced into a mould as threatening "enemy." The fact that the Lamb conquers the Beast in a sense only emphasises this precarious state.

The Whore too is caught up in this logic of sovereign power over the animal other. Closely affiliated with the Beast, she too is deemed beastly. Her blood-drinking denotes a predatory ferocity; as if an animal carcass, she is to be burned, or perhaps the burning is a form of cooking preparation before she is "devoured" as if her body has become meat (I7:I6). In the York Minster Great East window (ca. I 400), the Whore is depicted holding her cup with a frog climbing out of it, a snake curled around her shoulder. ${ }^{61}$ In the Hebrew Bible and New Testament, frogs are frequently symbols of evil and this symbolism endured into the medieval era where frogs were used to symbolise heresy, greed, evil, and $\sin .{ }^{62}$ The frog and snake further "animalise" the Whore, to the extent that she too might be seen as a womananimal hybrid with many animal parts, akin to the Beast she rides. In the destruction of her body she is stripped of the marks of her personhood, her clothes and jewellery, and her flesh is made naked as if an animal. These materials are, after all, proper to humans. Like the Beast the woman becomes "the living thing to be subjected, dominated, domesticated, mastered." 63 The Whore's animal nature is inextricably caught up in sexualised imagery. It is

and Administration (London: Routledge, 1994).

${ }^{59}$ Gilhus, Animals, Gods, and Humans, 32.

${ }^{60}$ Ibid., 33 .

${ }^{61}$ O'Hear and O'Hear, Picturing the Apocalypse, I64.

${ }^{62}$ Ibid., I 64-65.

${ }^{63}$ Derrida, The Beast, I:66. 
her status as a prostitute that lends her an ugliness that becomes perpetuated throughout the ages as an archetypal female evil. In Otto Dix's Der Krieg series from 1924, for instance, the Whore is imagined as an unattractive prostitute in a French brothel run by the German army during the First World War. ${ }^{64}$ She stands for the repulsive, manipulating force over soldiers.

Jennifer Glancy and Stephen Moore propose that readings of Revelation have been too "bookish" in their dealings with the Whore of Babylon, thus masking the way the Whore is specifically a whore. ${ }^{65}$ Glancy and Moore focus on the way in which the Whore is akin to a brothel or street prostitute rather than a courtesan. They argue that the references to porneia ( $\pi$ opvei $\alpha$ ) "would have conjured up first and foremost in the minds of the urban Christians addressed in Revelation a certain category of flesh-and-blood person" rather than a figure of high-class literature and art in the form of a courtesan. ${ }^{66} \mathrm{Be}-$ cause prostitution was not illegal or seen to be breaking moral laws, as it was not considered adultery, prostitutes in the Roman Empire were generally left alone, unprotected. ${ }^{67}$ As Robert Knapp writes in his book Invisible Romans, prostitutes had very little protection and the frequent conflation of prostitutes with slaves meant that these women were considered "fair game" when it came to social and physical abuse. ${ }^{68}$ While prostitution was a source of income, and was recognised by the law in being a taxable trade, ${ }^{69}$ it frequently fell upon the vulnerable. Sarah B. Pomeroy, for instance, notes that baby girls and daughters were sometimes sold into prostitution by their parents, ${ }^{70}$ and it can be assumed that dire poverty led many women into prostitution, into a status lower even than slaves, whose welfare was at least maintained according to their value in a household. ${ }^{71}$ It goes without saying that this was frequently a dangerous life, most often located at the bottom of the social order. In Rev 17 the Whore of Babylon as a symbol of Rome taps into this imagery of prostitution, and is crucially reinforced by the "animalisation" of

${ }^{64}$ O'Hear and O'Hear, Picturing the Apocalypse, I7 I.

${ }^{65}$ Jennifer A. Glancy and Stephen D. Moore, "How Typical a Roman Prostitute is Revelation's 'Great Whore?" Journal of Biblical Literature I30, no. 3 (20I I), 552.

${ }^{66}$ Ibid., 557.

${ }^{67}$ Robert Knapp, Invisible Romans: Prostitutes, Outlaws, Gladiators, Ordinary Men and Women ... The Romans that History Forgot (London: Profile Books, 2013), 239.

${ }^{68}$ Ibid., 26I.

${ }^{69}$ Sarah B. Pomeroy, Goddesses, Whores, Wives, and Slaves: Women in Classical Antiquity (New York: Schocken Books, I975), 20 I.

${ }^{70}$ Ibid., I 92.

${ }^{71}$ Ibid., 202. 
the Whore to exploit the most efficacious mode of conjuring up antipathy. The destruction of the Whore is, as Tina Pippin comments, the ultimate misogynist fantasy. ${ }^{72}$

Employing prostitution associated with an animalised female to characterise evil here conjures up antipathy rather than compassion, just as the beasts of the Roman arena are used to evoke aversion, not pity. The way the goddess Roma, a "queen" ( $18: 7$ ), is frequently identified as a parody in being dressed up and paraded as a prostitute might point to the way the imagery is strategically employed but does not offer pause in thinking about whether she could, or ought, to be seen otherwise. By disallowing this imagery to simply "speak" as if a smooth and glossy surface without the dark and gritty realities that inform them, I have tried to show that the logic of sympathy and antipathy breaks down and the Whore and Beast might paradoxically invoke compassion.

Rather than depicting the Roman Empire as a revolting sovereign power that must - in light of its abject evil—be conquered, a closer examination of the Whore of Babylon, like the animals of the Roman arena, reveals the vulnerable and suffering victims of Roman society, denigrated to a category of "nonhuman," and residing in a space of suffering. In this sense, the political logic of the Lamb as the sympathetic sovereign power in view of its suffering innocence is overturned as it becomes a superlative sovereign power, and the Whore and the Beast become the powerless suffering animals of the political order, at the mercy of the "reason of the strongest." What Rev I7 plays out is a power struggle between two competing sovereignties, one construed as the innocent good, and the other as an evil, beastly-female other. The sympathy set up is for the Lamb as the innocent, weak, suffering side, against the ferocious, repellent Whore-and-Beast. But the Lamb as sovereign conqueror feeds on a "reason of the strongest" in order to establish that sovereignty is proper only, exclusively to itself. If such a battle for sovereignty is fought on the grounds that one side is set up as a legitimate sovereignty, sympathetic and superior as a saving and suffering innocent figure in the form of a Lamb, such a logic of sympathy and antipathy collapses when the Lamb becomes the figure of ultimate sovereignty and the Whore and Beast are divulged as weak, suffering victims. ${ }^{73}$ Rather than promote a weak force, the Christian imagination here seemingly plays into a reason of the strongest in the contest for

${ }^{72}$ Pippin, Death and Desire, 57-68.

${ }^{73}$ Of course, the image of the Lamb is more complex. A case could be made for the slain Lamb embodying a victim-position in the same way the Whore and the Beast end up doing, 
sovereignty, and this imaginary can be seen in many of the later depictions of the Lamb and its enemies. But it could also be argued that the biblical text subtly subverts such clear-cut oppositions at the same time as it proffers them. As the superlative sovereignty shifts onto the Lamb, does the sympathy shift to the Whore-and-Beast? Or, as the Whore and the Beast are "unpackaged" as victims of Roman society, does the whole dichotomy between good and evil become muddied and confused? Where ought sympathy to lie?

Revealed as the "animals" they are, the Beast and the Whore in this reading become in a sense what Derrida describes as a deconstructed sovereignty; that is, embodying a sovereignty that is shared, mortal, vulnerable rather than indivisible. Such a "revelation" is a recognition of the suffering and mortality of animals and humans alike in complex networks of power, of the divisibility and diffuseness of the limits and lines that separate the "human" from the "animal," or sovereign from non-sovereign. "If these images are 'pathetic,' if they evoke sympathy, it is also because they 'pathetically' open the immense question of pathos and the pathological, precisely, that is, of suffering, pity, and compassion." 74 In other words, the "patheticness" these images might evoke should open up the question of pathos; should provoke us to ask what place suffering has in the political realm, and in what ways compassion can be carved out as a political issue. Derrida argues for "the place that has to be accorded to the interpretation of this compassion, to the sharing of this suffering among the living, to the law, ethics, and politics that must be brought to bear upon this experience of compassion." ${ }^{\prime 75}$ It is for him a matter of awakening "to our responsibilities and our obligations vis-à-vis the living in general" and to a fundamental compassion. ${ }^{76}$ Peggy Kamuf insists that wakefulness for Derrida is "the very condition or possibility of critical reception and inheritance." 77 Such a wakefulness might prompt us to think about how such a critical reception impinges also on our practices in the present.

also as a deconstructed sovereignty. It certainly is given characteristics that perform a strong sovereignty that is destructive of its "animal" other, but it is of course itself at the same time a "slain Lamb" (Rev 5:6). Perhaps the reception of the Lamb in art reflects this paradoxical, or dual, nature. As O'Hear and O'Hear testify, some Norman manuscripts and tapestries, as well as pieces by Albrecht Dürer and Georg Friedrich Handel, for instance, display versions of the Lamb as nationalistic, sovereign, and triumphant, while William Blake, on the other hand, depicts a meek Lamb: Picturing the Apocalypse, $6 \mathrm{I}$.

${ }^{74}$ Derrida, The Animal, 26.

${ }^{75}$ Ibid.

${ }^{76}$ Ibid., 27.

${ }^{77}$ Peggy Kamuf, To Follow: The Wake of Jacques Derrida (Edinburgh: Edinburgh University Press, 20 го), го. 


\section{A Political-Biblical "Fable"}

If Rev 17 could be described as a (theo)political fable ${ }^{78}$ that has become popularly adapted in different historical circumstances, what is the "lesson" I have proposed in my rewiring of its well-known characters? What I have tried to propose is that the female-animal assemblage for political evil could be assembled otherwise; that in fact the text might "do" other things than merely depict a good and innocent sovereignty (the Lamb) against an evil sovereignty that must be destroyed (Whore-and-Beast). In some ways the text undoes its own dichotomy by the logic of the weak and innocent Lamb overturning as it becomes the conquering Lord of lords. In a battle of sovereignties no one can remain the innocent, righteous party. A reason of the strongest is at play that involves a violent demonization, or rather, animalisation of the other. As Elisabeth Roudinesco comments, animality has long functioned as a way of operating systemic exclusions in terms of racism, sexism, and antisemitism by assigning "an inferior status to someone in order to exclude him (or her) from the human, to stigmatize him by virtue of physical traits that would place him within the world of animality." 79 To think a deconstructed sovereignty that resists notions of the sovereign human (or man) with traits proper to himself, and that thus operates as a mechanism for exclusion, is to recognise the shared mortality and capacity for suffering amongst the living. It is to recognise, as Derrida's title has it, the animal that therefore I am, without losing the sense of "irreducible differences." 80 This is necessary so as not to provide "a pretext for giving ourselves over to the worst kinds of violence," legitimated precisely because the other is made "animal." ${ }^{81}$

Crucially, political evil is not arbitrarily dressed up in the garb of animality (or female-animality). Rather, it maintains and produces an antipathy that seeks to foreclose pity by associating the animal with what is deemed necessary to exclude from the "proper" human realm such as brutality, depravity, and instinct. It is thus possible, as Derrida points out, and even easy, to "organize on a global scale the forgetting or misunderstanding" of

${ }^{78} \mathrm{I}$ use this term in the loosest sense, merely to denote a story involving animal characters that bear some kind of moral lesson. Moore also refers to Revelation as falling loosely within the fable tradition: "Ecotherology," I 97.

${ }^{79}$ Jacques Derrida and Elisabeth Roudinesco, For What Tomorrow ... A Dialogue, trans. Jeff Fort (Stanford: California University Press, 2004), 69.

${ }^{80}$ Ibid., 66.

${ }^{81}$ Ibid., 73 . 
organised violence against animals. ${ }^{82}$ By refusing to allow simplistic characterisations of evil to linger in the popular imagination the spell might be broken, by revealing the apparatus that upholds indifference or denial of "the suffering, fear, or panic, the terror or fright that can seize certain animals and that we humans can witness." 83 Revealing the prostitutes and the captured animals of Rome is a way of drawing attention to the suffering that is otherwise masked by caricatured images and reductive representations. Is it a matter of seeing, then, or indeed of reading, of witnessing otherwise? It might be a case of refusing to see according to the gloss that is given in depicting evil as animal, as female-animal. And, further, of looking beyond the gloss to the dark details that are lost in the sheen of simplistic us-and-them rhetoric and imagery. Beyond that it might indeed be necessary to reflect critically on how the experience of compassion, of pathos, can be brought to bear more seriously on the realm of the political. From the large-scale predatory arena variety to the small-scale but equally (if differently) potent imagery of insects or rats, there can be no innocent sovereignty that does not play into a (violent) reason of the strongest when the "beastly" other must at best be ousted and at worst be unequivocally quashed, or as with the Whore, laid bare and eaten.

${ }^{82}$ Derrida, The Animal, 26.

${ }^{83}$ Ibid., 28. 